\title{
Muricauda flavescens sp. nov. and Muricauda aquimarina sp. nov., isolated from a salt lake near Hwajinpo Beach of the East Sea in Korea, and emended description of the genus Muricauda
}

\author{
Jung-Hoon Yoon, ${ }^{1}$ Mi-Hwa Lee, ${ }^{1}$ Tae-Kwang $\mathrm{Oh}^{1}$ and Yong-Ha Park ${ }^{1,2}$ \\ ${ }^{1}$ Korea Research Institute of Bioscience and Biotechnology (KRIBB), PO Box 115, Yusong, \\ Taejon, Korea \\ ${ }^{2}$ National Research Laboratory of Molecular Ecosystematics, Institute of Probionic, Probionic \\ Corporation, Bio-venture Center, Korea Research Institute of Bioscience and Biotechnology \\ (KRIBB), PO Box 115, Yusong, Taejon, Korea
}

Correspondence

Jung-Hoon Yoon

jhyoon@kribb.re.kr

Four Gram-negative, non-spore-forming, slightly halophilic rods (strains SW-62 ${ }^{\top}, \mathrm{SW}-74$, SW-63 ${ }^{\top}$ and SW-72) with appendages were isolated from a salt lake near Hwajinpo Beach on the East Sea in Korea, and subjected to a polyphasic taxonomic analysis. Phylogenetic analyses based on $16 \mathrm{~S}$ rRNA gene sequences showed that strains SW- $62^{\top}, \mathrm{SW}-74, \mathrm{SW}-63^{\top}$ and SW-72 formed a coherent cluster with Muricauda ruestringensis. Strains SW-62 ${ }^{\top}$ and SW-74 had the same $16 \mathrm{~S}$ rRNA gene sequence, as did strains $S W-63^{\top}$ and $S W-72$. The level of $16 \mathrm{~S}$ rRNA gene sequence similarity between strains $S W-62^{\top}$ and $S W-63^{\top}$ was $97 \cdot 0 \%$. Strains SW $-62^{\top}$ and SW $-63^{\top}$ exhibited $16 \mathrm{~S}$ rRNA gene similarity levels of $96 \cdot 5$ and $98 \cdot 3 \%$, respectively, with respect to $M$. ruestringensis DSM $13258^{\top}$. The predominant isoprenoid quinone found in the four isolates and $M$. ruestringensis DSM $13258^{\top}$ was MK-6. The four strains contained iso- $\mathrm{C}_{17: 0} 3-\mathrm{OH}$, iso- $\mathrm{C}_{15: 1}$ and iso- $\mathrm{C}_{15: 0}$ as the major fatty acids. Their DNA $\mathrm{G}+\mathrm{C}$ contents were 44.1-45.4 mol\%. The levels of DNA-DNA relatedness indicated that strains $S W-62^{\top}$ and SW-74 and strains SW-63 ${ }^{\top}$ and SW-72 were members of two species that were different from $M$. ruestringensis. On the basis of phenotypic and phylogenetic data and genomic distinctiveness, strains SW-62 ${ }^{\top}$ and SW-74 and strains SW-63 ${ }^{\top}$ and SW-72 were placed in the genus Muricauda as two distinct novel species, for which the names Muricauda flavescens sp. nov. (type strain, SW-62 ${ }^{\top}=\mathrm{KCCM} 41645^{\top}=\mathrm{JCM} 11812^{\top}$ ) and Muricauda aquimarina sp. nov. (type strain, SW-63 ${ }^{\top}=\mathrm{KCCM} 41646^{\top}=\mathrm{JCM} 11811^{\top}$ ), respectively, are proposed.

In the course of screening for taxonomically useful microorganisms present in a salt lake near Hwajinpo Beach of the East Sea in Korea, many halophilic or halotolerant bacteria have been isolated and characterized taxonomically. Of these isolates, four strains $\left(\mathrm{SW}-62^{\mathrm{T}}, \mathrm{SW}-74, \mathrm{SW}-63^{\mathrm{T}}\right.$ and SW-72) were focused on in this study because they were found to have an interesting morphological property in that they possessed an appendage. The results of $16 \mathrm{~S}$ rRNA gene

Published online ahead of print on 3 December 2004 as DOI 10.1099/ ijs.0.03051-0.

Abbreviation: CFB, Cytophaga-Flavobacterium-Bacteroides.

The GenBank/EMBL/DDBJ accession numbers for the 16S rRNA gene sequences of strains SW-62 ${ }^{\top}, \mathrm{SW}-74, \mathrm{SW}-63^{\top}$ and SW-72 are AY445073, AY445074, AY445075 and AY445076, respectively.

Transmission electron micrographs showing the appendages found on most cells of strains SW- $62^{\top}$, SW-74, SW- $63^{\top}$ and SW-72 are available as supplementary material in IJSEM Online. sequence comparisons indicated that the four strains are phylogenetically related to the genus Muricauda. The genus Muricauda was proposed by Bruns et al. (2001) with the single species Muricauda ruestringensis. Phylogenetic analysis based on 16S rRNA gene sequences showed that the genus Muricauda is a member of the family Flavobacteriaceae within the Cytophaga-Flavobacterium-Bacteroides (CFB) complex (Bruns et al., 2001). At the time of writing, there is only one Muricauda species with a validly published name (Bruns et al., 2001). The aim of the present study was to investigate the possibility that strains SW$62^{\mathrm{T}}, \mathrm{SW}-74, \mathrm{SW}-63^{\mathrm{T}}$ and SW-72 were novel species of the genus Muricauda. In this work, we describe the morphological, phenotypic, phylogenetic and genomic characteristics of strains SW-62 ${ }^{\mathrm{T}}, \mathrm{SW}-74, \mathrm{SW}-63^{\mathrm{T}}$ and $\mathrm{SW}-72$.

Strains SW-62 ${ }^{\mathrm{T}}$, SW-74, SW-63 ${ }^{\mathrm{T}}$ and SW-72 were isolated by using the standard dilution plating technique on marine agar 2216 (MA; Difco). For isoprenoid quinone analysis 
and DNA extraction, cell biomass of the four isolates and M. ruestringensis DSM $13258^{\mathrm{T}}$ was obtained after cultivation in marine broth 2216 (MB; Difco) for 2 days at $30^{\circ} \mathrm{C}$. For fatty acid methyl ester analysis, cell mass of the four isolates and M. ruestringensis DSM $13258^{\mathrm{T}}$ was obtained from agar plates after incubation for 3 days at $30^{\circ} \mathrm{C}$ on MA. M. ruestringensis DSM $13258^{\mathrm{T}}$ was obtained from the DSMZ (Deutsche Sammlung von Mikroorganismen und Zellkulturen, Braunschweig, Germany). Cell morphology was examined by using light microscopy (E600 apparatus; Nikon) and transmission electron microscopy (CM-20 apparatus; Philips). Gram reactions were determined using the bioMérieux Gram stain kit according to the manufacturer's instructions. Growth under anaerobic conditions was determined after incubation in an anaerobic chamber on MA and MA supplemented with nitrate, both of which had been prepared anaerobically using nitrogen. Growth in the absence of $\mathrm{NaCl}$ was investigated in trypticase/soy broth (Difco) lacking $\mathrm{NaCl}$. Growth at various $\mathrm{NaCl}$ concentrations was investigated for 14 days at $30{ }^{\circ} \mathrm{C}$ in MB. Growth at various temperatures was measured on MA at $4-50^{\circ} \mathrm{C}$. Catalase and oxidase activities and hydrolysis of casein and starch were determined as described by Cowan \& Steel (1965). Hydrolysis of aesculin, urea and gelatin and nitrate reduction were studied as described previously (Lanyi, 1987) with the modification that artificial sea water was used. The artificial sea water contained the following (per litre of distilled water): $23.6 \mathrm{~g} \mathrm{NaCl}$, $0.64 \mathrm{~g} \mathrm{KCl}, 4.53 \mathrm{~g} \mathrm{MgCl}_{2} \cdot 6 \mathrm{H}_{2} \mathrm{O}, 5.94 \mathrm{~g} \mathrm{MgSO}_{4} .7 \mathrm{H}_{2} \mathrm{O}$ and $1.3 \mathrm{~g} \mathrm{CaCl}_{2} \cdot 2 \mathrm{H}_{2} \mathrm{O}$ (Bruns et al., 2001). Hydrolysis of Tweens 20, 40, 60 and 80 was determined as described by Cowan \& Steel (1965) or tested on MA using the substrate concentrations described by Cowan \& Steel (1965). Hydrolysis of hypoxanthine, tyrosine and xanthine was tested on MA plates with the substrate concentrations described previously (Cowan \& Steel, 1965). Hydrolysis of birchwood xylan (Sigma) was tested on solid marine salts basal medium (Baumann \& Baumann, 1981) supplemented with $0.5 \%(\mathrm{w} / \mathrm{v})$ xylan as the sole carbon source. $\mathrm{H}_{2} \mathrm{~S}$ production was tested as described previously (Bruns et al., 2001). Acid production from carbohydrates was determined as described by Leifson (1963). Utilization of various substrates for growth was determined as described by Yurkov et al. (1994).

Isoprenoid quinones were analysed as described by Komagata \& Suzuki (1987), using reversed-phase HPLC. For quantitative analysis of cellular fatty acid compositions, a loop of cell mass was harvested and fatty acid methyl esters were extracted and prepared according to the standard protocol of the MIDI/Hewlett Packard Microbial Identification System (Sasser, 1990). Chromosomal DNA was isolated and purified according to the method described previously (Yoon et al., 1996), with the exception that ribonuclease $\mathrm{T} 1$ was used with ribonuclease $\mathrm{A}$. The DNA G + C content was determined by the method of Tamaoka \& Komagata (1984). DNA was hydrolysed and the resultant nucleotides were analysed by reversed-phase
HPLC. The 16S rRNA gene was amplified by a PCR using two universal primers, as described previously (Yoon et al., 1998). Sequencing of the amplified 16S rRNA gene and phylogenetic analysis were performed as described by Yoon et al. (2003). DNA-DNA hybridization was performed fluorometrically according to the method of Ezaki et al. (1989), using photobiotin-labelled DNA probes and microdilution wells. Hybridization was performed using five replications for each sample. Of the values obtained, the highest and lowest for each sample were excluded. DNADNA relatedness values are the means of the remaining three values.

The colonies of strains SW-62 ${ }^{\mathrm{T}} \mathrm{SW}-74, \mathrm{SW}-63^{\mathrm{T}}$ and SW-72 were golden yellow in colour on MA, whereas those of M. ruestringensis DSM $13258^{\mathrm{T}}$ were yellow on MA. Acid production from D-melezitose was observed only for strains SW-62 ${ }^{\mathrm{T}}$ and SW-74. Other morphological, cultural, physiological and biochemical characteristics are shown in Table 1 or are given in the species descriptions (see below). Strains SW-62 ${ }^{\mathrm{T}} \mathrm{SW}-74, \mathrm{SW}-63^{\mathrm{T}}$ and SW-72 contained unsaturated menaquinone with six isoprene units (MK-6) as the predominant isoprenoid quinone. In this study, the predominant isoprenoid quinone of M. ruestringensis DSM $13258^{\mathrm{T}}$ was also analysed and found to be MK-6. Strains SW-62 ${ }^{\mathrm{T}}$ SW-74, SW-63 ${ }^{\mathrm{T}}$ and SW-72 had cellular fatty acid profiles containing large amounts of straight-chain, branched and hydroxy fatty acids; the major fatty acids were iso- $\mathrm{C}_{17: 0} 3-\mathrm{OH}$, iso- $\mathrm{C}_{15: 1}$ and iso- $\mathrm{C}_{15: 0}$ (Table 2). These fatty acid profiles were similar to that of M. ruestringensis DSM $13258^{\mathrm{T}}$ (analysed in this study; see Table 2 ). For some fatty acids, particularly $\mathrm{C}_{15: 0}$, the proportions present in $M$. ruestringensis DSM $13258^{\mathrm{T}}$ differed between this study and the study of Bruns et al. (2001), perhaps because of differences in cultivation conditions. The DNA G $+C$ contents of strains SW $-62^{\mathrm{T}}$, SW-74, SW- $63^{\mathrm{T}}$ and SW-72 were $45 \cdot 2,45 \cdot 4,44 \cdot 1$ and $44 \cdot 2 \mathrm{~mol} \%$, respectively.

The 16S rRNA gene sequences of strains SW $-62^{\mathrm{T}}$, SW-74, SW $-63^{\mathrm{T}}$ and SW-72 determined in this study each comprised $1481 \mathrm{nt}$, representing approximately $96 \%$ of the Escherichia coli 16S rRNA sequence. The results of $16 \mathrm{~S}$ rRNA gene sequence comparisons showed that the sequences of strains SW- $62^{\mathrm{T}}$ and SW-74 were identical to each other; so also were strains $\mathrm{SW}-63^{\mathrm{T}}$ and $\mathrm{SW}-72$. The level of $16 \mathrm{~S}$ rRNA gene sequence similarity between strain $\mathrm{SW}-62^{\mathrm{T}}$ and strain SW- $63^{\mathrm{T}}$ was $97 \cdot 0 \%$. Phylogenetic trees based on $16 \mathrm{~S}$ rRNA gene sequences demonstrated that the four strains form the radiation of the cluster with $M$. ruestringensis. In the phylogenetic tree based on the neighbour-joining algorithm (Yoon et al., 2003), strains SW-63 ${ }^{\mathrm{T}}$ and SW-72 formed a coherent cluster with $M$. ruestringensis DSM $13258^{\mathrm{T}}$ at a bootstrap resampling value of $96.4 \%$; this cluster joined strains SW- $62^{\mathrm{T}}$ and SW-74 at a bootstrap resampling value of $100 \%$ (Fig. 1). Strains $\mathrm{SW}-62^{\mathrm{T}}$ and SW-74 and strains SW-63 ${ }^{\mathrm{T}}$ and SW-72 exhibited $16 \mathrm{~S}$ rRNA gene sequence similarity levels of $96 \cdot 5$ and $98 \cdot 3 \%$, 


\section{Table 1. Phenotypic characteristics of Muricauda species}

1, M. flavescens; 2, M. aquimarina; 3, M. ruestringensis. All species are rod-shaped. The following tests are positive for all species: oxidase (data from this study); hydrolysis of aesculin (this study), tyrosine (this study), Tweens 20, 40, 60 and 80 (all this study); growth on fructose, succinate (this study), raffinose, cellobiose, sucrose, lactose and mannose; and acid production from Dfructose, melibiose, D-glucose, D-mannose, D-cellobiose, lactose, sucrose, maltose, D-trehalose and D-raffinose. The following tests are negative for all species: Gram stain; spore formation; growth in $0 \% \mathrm{NaCl}$ and at $4{ }^{\circ} \mathrm{C}$; nitrate reduction; $\mathrm{H}_{2} \mathrm{~S}$ production; hydrolysis of casein (this study), gelatin, hypoxanthine (this study), starch, urea (this study) and xanthine (this study); growth on acetate, pyruvate, glutamate (this study), butyrate (this study), citrate (this study), lactate (this study), formate (this study), methanol (this study), ethanol, benzoate (this study), serine, mannitol and hexadecane; and acid production from D-sorbitol, myo-inositol, D-ribose, D-mannitol, adonitol and L-rhamnose. Symbols: + , positive; - , negative.

\begin{tabular}{|lccc|}
\hline Characteristic & $\mathbf{1}$ & $\mathbf{2}$ & $\mathbf{3}^{*}$ \\
\hline Catalase & + & + & $-\dagger$ \\
Facultative anaerobe & - & - & + \\
Optimal temp. for growth $\left({ }^{\circ} \mathrm{C}\right)$ & $30-37$ & $30-37$ & $20-30$ \\
Growth on: & & & \\
$\quad$ Glucose & + & + & - \\
Malate & - & - & + \\
Alanine & - & - & + \\
Arginine & - & - & + \\
Acid production from: & & & \\
D-Xylose & - & - & + \\
L-Arabinose & - & - & + \\
D-Melezitose & + & - & + \\
D-Galactose & - & - & + \\
DNA G+C content $(\mathrm{mol} \%)$ & $45 \cdot 2-45 \cdot 4$ & $44 \cdot 1-44 \cdot 2$ & 41 \\
\end{tabular}

${ }^{\star}$ Data from Bruns et al. (2001).

$\dagger$ Positive in this study.

$\ddagger$ Data for $M$. ruestringensis from this study.

respectively, with respect to the type strain of $M$. ruestringensis (Fig. 1). The four isolates exhibited levels of $16 \mathrm{~S}$ rRNA gene sequence similarity of less than $91 \cdot 6 \%$ (between strains SW-63 ${ }^{\mathrm{T}}$ and SW-72 and Zobellia uliginosa ATCC $14397^{\mathrm{T}}$ ) to other species used in the phylogenetic analysis (Fig. 1). Levels of DNA-DNA relatedness between strains SW $-62^{\mathrm{T}}$ and SW-74 and between strains SW $-63^{\mathrm{T}}$ and SW-72 were 90.7 and $93.6 \%$, respectively. The mean level of DNADNA relatedness between strains $\mathrm{SW}-62^{\mathrm{T}}$ and $\mathrm{SW}-74$ and strains $\mathrm{SW}-63^{\mathrm{T}}$ and $\mathrm{SW}-72$ was $9 \cdot 2 \%$. Strains $\mathrm{SW}-62^{\mathrm{T}}$ and SW- $63^{\mathrm{T}}$ exhibited DNA-DNA relatedness levels of 4.9 and $7 \cdot 0 \%$, respectively, with respect to $M$. ruestringensis DSM $13258^{\mathrm{T}}$.

Preliminary studies on micro-organisms present in a salt lake near Hwajinpo Beach on the East Sea in Korea have
Table 2. Cellular fatty acid composition (\%) of strains SW-62 ${ }^{\top}$, SW-74, SW-63 ${ }^{\top}$ and SW-72 and M. ruestringensis DSM $13258^{\top}$ on MA

1, SW-62 ${ }^{\mathrm{T}} ; 2$, SW-74; 3, SW-63 ${ }^{\mathrm{T}} ; 4$, SW-72; 5, DSM $13258^{\mathrm{T}}$. Fatty acids representing less than $0.5 \%$ in all strains were omitted. -, Not detected.

\begin{tabular}{|c|c|c|c|c|c|}
\hline Fatty acid & 1 & 2 & 3 & 4 & 5 \\
\hline \multicolumn{6}{|c|}{ Straight-chain fatty acids } \\
\hline $\mathrm{C}_{15: 0}$ & $12 \cdot 4$ & $11 \cdot 9$ & $5 \cdot 9$ & $5 \cdot 1$ & $13 \cdot 2$ \\
\hline$C_{16: 0}$ & $0 \cdot 6$ & $0 \cdot 6$ & $0 \cdot 4$ & $0 \cdot 2$ & $0 \cdot 4$ \\
\hline \multicolumn{6}{|l|}{ Branched fatty acids } \\
\hline iso- $\mathrm{C}_{14: 0}$ & - & - & $0 \cdot 6$ & $0 \cdot 7$ & - \\
\hline iso- $\mathrm{C}_{15: 0}$ & $16 \cdot 4$ & $15 \cdot 7$ & $23 \cdot 7$ & $23 \cdot 8$ & $14 \cdot 7$ \\
\hline iso- $\mathrm{C}_{15: 1} \mathrm{G}^{*}$ & $19 \cdot 9$ & $19 \cdot 5$ & $21 \cdot 6$ & $21 \cdot 1$ & $20 \cdot 5$ \\
\hline anteiso- $\mathrm{C}_{15: 0}$ & $2 \cdot 1$ & $2 \cdot 0$ & $2 \cdot 0$ & $2 \cdot 5$ & $1 \cdot 1$ \\
\hline iso- $\mathrm{C}_{16: 0}$ & $0 \cdot 6$ & $0 \cdot 6$ & $0 \cdot 5$ & $0 \cdot 5$ & - \\
\hline iso- $\mathrm{C}_{17: 1} \omega 9 c$ & $1 \cdot 3$ & $1 \cdot 3$ & $1 \cdot 5$ & $1 \cdot 4$ & $1 \cdot 4$ \\
\hline \multicolumn{6}{|c|}{ Unsaturated fatty acids } \\
\hline $\mathrm{C}_{15: 1} \omega 6 c$ & $0 \cdot 9$ & $0 \cdot 9$ & $0 \cdot 9$ & $0 \cdot 8$ & $0 \cdot 9$ \\
\hline $\mathrm{C}_{17: 1} \omega 6 c$ & $0 \cdot 5$ & $0 \cdot 7$ & $0 \cdot 5$ & $0 \cdot 4$ & $1 \cdot 0$ \\
\hline $\mathrm{C}_{17: 1} \omega 8 c$ & $0 \cdot 4$ & $0 \cdot 4$ & - & $0 \cdot 2$ & $0 \cdot 7$ \\
\hline \multicolumn{6}{|l|}{ Hydroxy fatty acids } \\
\hline $\mathrm{C}_{15: 0} 2-\mathrm{OH}$ & $0 \cdot 6$ & $0 \cdot 6$ & $0 \cdot 2$ & $0 \cdot 3$ & $0 \cdot 5$ \\
\hline $\mathrm{C}_{15: 0} 3-\mathrm{OH}$ & $1 \cdot 0$ & $1 \cdot 0$ & $1 \cdot 4$ & $1 \cdot 6$ & $1 \cdot 8$ \\
\hline iso- $\mathrm{C}_{15: 0} 3-\mathrm{OH}$ & $4 \cdot 7$ & $5 \cdot 0$ & $5 \cdot 2$ & $5 \cdot 5$ & $4 \cdot 6$ \\
\hline $\mathrm{C}_{16: 0} 3-\mathrm{OH}$ & $0 \cdot 8$ & $0 \cdot 9$ & $0 \cdot 6$ & $0 \cdot 7$ & $0 \cdot 4$ \\
\hline iso- $\mathrm{C}_{16: 0} 3-\mathrm{OH}$ & $2 \cdot 9$ & $3 \cdot 0$ & $4 \cdot 0$ & $4 \cdot 6$ & $1 \cdot 7$ \\
\hline $\mathrm{C}_{17: 0} 2-\mathrm{OH}$ & $1 \cdot 3$ & $1 \cdot 4$ & $0 \cdot 7$ & $0 \cdot 9$ & $0 \cdot 7$ \\
\hline $\mathrm{C}_{17: 0} 3-\mathrm{OH}$ & $0 \cdot 7$ & $0 \cdot 8$ & $0 \cdot 3$ & $0 \cdot 4$ & $1 \cdot 3$ \\
\hline iso- $\mathrm{C}_{17: 0} 3-\mathrm{OH}$ & $19 \cdot 9$ & $20 \cdot 4$ & $17 \cdot 3$ & $17 \cdot 7$ & $20 \cdot 9$ \\
\hline Summed feature $3 \dagger$ & $4 \cdot 1$ & $4 \cdot 2$ & $2 \cdot 3$ & $2 \cdot 7$ & $4 \cdot 2$ \\
\hline \multicolumn{6}{|l|}{ Unknown fatty acids $\ddagger$} \\
\hline $11 \cdot 543(\mathrm{ECL})$ & - & $0 \cdot 6$ & $0 \cdot 8$ & $0 \cdot 8$ & $0 \cdot 6$ \\
\hline $13 \cdot 565(\mathrm{ECL})$ & $5 \cdot 4$ & $5 \cdot 8$ & $4 \cdot 8$ & $4 \cdot 9$ & $6 \cdot 5$ \\
\hline $16 \cdot 582(\mathrm{ECL})$ & $1 \cdot 6$ & $1 \cdot 5$ & $1 \cdot 3$ & $1 \cdot 4$ & $1 \cdot 7$ \\
\hline
\end{tabular}

*The double bond positions indicated by upper-case letter are unknown.

†Summed feature 3 represents iso- $\mathrm{C}_{15: 0} 2-\mathrm{OH}$ and/or $\mathrm{C}_{16: 1} \omega 7 c$, which could not be separated by GLC with the MIDI system.

$\ddagger$ ECL, equivalent chain length.

shown that one of the major groups of bacterial isolates belongs to the CFB complex. The CFB complex is known to be predominant in marine environments, including sea water, intertidal sediments and Antarctic sea ice among others (Bowman et al., 1997; Pinhassi et al., 1997; LlobetBrossa et al., 1998; Glöckner et al., 1999; Barbeyron et al., 2001; Kirchman, 2002). Phylogenetic analysis based on $16 \mathrm{~S}$ rRNA gene sequences indicated that strains SW $-62^{\mathrm{T}}$, SW-74, SW-63 ${ }^{\mathrm{T}}$ and SW-72 are most closely related to the genus Muricauda, a member of the CFB complex. Their morphological properties are similar to those of $M$. ruestringensis; in particular, all possess an appendage not found in the phylogenetically related genus Zobellia 


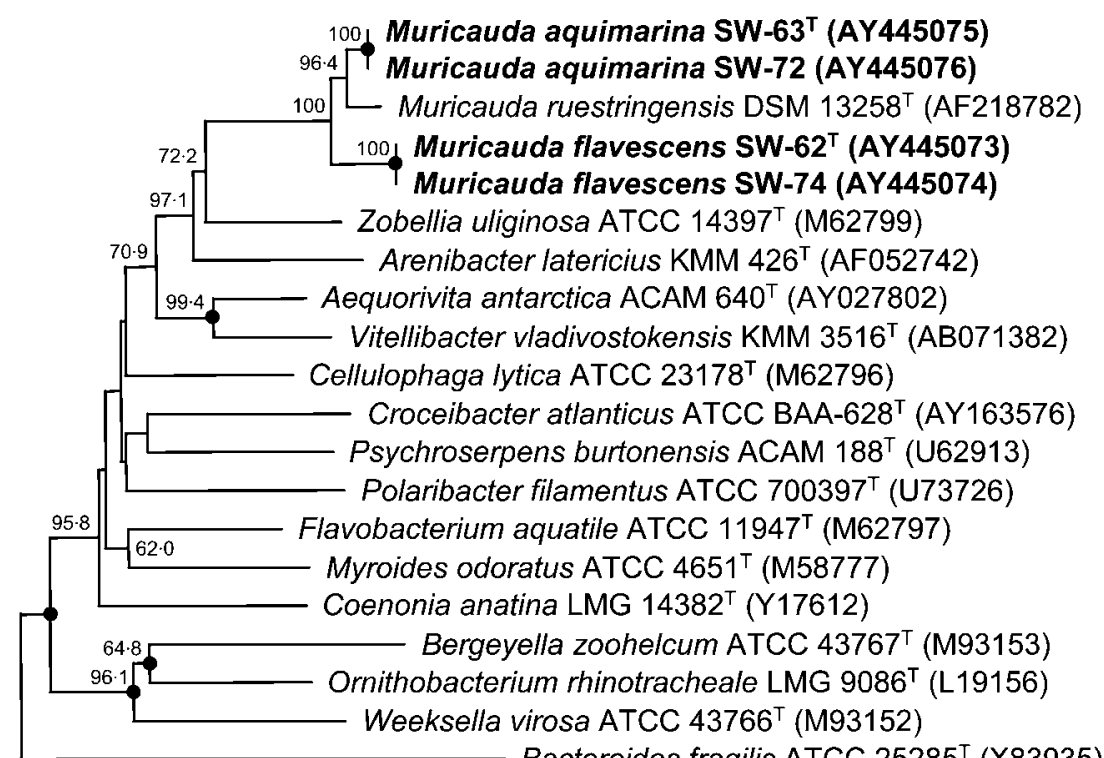

$0 \cdot 01$
Fig. 1. Neighbour-joining tree, based on 16S rRNA gene sequences, showing the phylogenetic positions of strains SW- $62^{\top}$, SW-74, SW-63 ${ }^{\top}$ and SW-72 and representatives of the family Flavobacteriaceae. Bootstrap values (expressed as percentages of 1000 replications) greater than $50 \%$ are shown at the branch points. Bacteroides fragilis ATCC $25285^{\top}$ was used as the outgroup. Solid circles indicate nodes that were also found in the maximum-likelihood tree. Bar, 0.01 substitution per nucleotide position.
(Barbeyron et al., 2001; Bruns et al., 2001). The results of chemotaxonomic analyses are consistent with the results of phylogenetic and morphological analyses. The chemotaxonomic properties of the four strains are similar to those of $M$. ruestringensis (Bruns et al., 2001). The fatty acid profiles of the genus Zobellia, the four strains and M. ruestringensis DSM $13258^{\mathrm{T}}$ are similar, but there are differences in the proportions of some fatty acids, particularly iso- $\mathrm{C}_{15: 1}$ (Barbeyron et al., 2001).

Strains SW-62 ${ }^{\mathrm{T}}$, SW-74, SW-63 ${ }^{\mathrm{T}}$ and SW-72 were found to have almost identical cultural and physiological characteristics (Table 1). There are no sequence differences in $16 \mathrm{~S}$ rRNA gene sequences between strains $\mathrm{SW}-62^{\mathrm{T}}$ and $\mathrm{SW}-74$ or between strains $\mathrm{SW}-63^{\mathrm{T}}$ and $\mathrm{SW}-72$. DNA-DNA relatedness values indicate that strains $\mathrm{SW}-62^{\mathrm{T}}$ and $\mathrm{SW}-74$ and strains $\mathrm{SW}-63^{\mathrm{T}}$ and $\mathrm{SW}-72$ are members of two different genomic species (Wayne et al., 1987). Strains SW-62 ${ }^{\mathrm{T}}$ and SW-74 and strains $\mathrm{SW}-63^{\mathrm{T}}$ and SW-72 are similar to $M$. ruestringensis in most physiological characteristics, except growth on some substrates and acid production from some sugars (Table 1). While $M$. ruestringensis grows in anaerobic conditions, the four isolates do not grow in anaerobic conditions on MA or on MA supplemented with nitrate. Strains SW-62 ${ }^{\mathrm{T}}$ and SW-74 and strains SW$63^{\mathrm{T}}$ and SW-72 are phylogenetically and genetically distinguishable from M. ruestringensis (Wayne et al., 1987; Stackebrandt \& Goebel, 1994). Therefore, on the basis of the data presented above, strains SW-62 ${ }^{\mathrm{T}}$ and SW-74 and strains $S W-63^{\mathrm{T}}$ and $\mathrm{SW}-72$ should be placed in the genus Muricauda as two distinct novel species, for which the names Muricauda flavescens sp. nov. and Muricauda aquimarina sp. nov., respectively, are proposed.

\section{Emended description of the genus Muricauda Bruns et al. 2001}

The description is as given previously (Bruns et al., 2001), with the following amendments. Facultatively anaerobic or strictly aerobic. Optimal growth occurs between 20 and $30{ }^{\circ} \mathrm{C}$ or between 30 and $37^{\circ} \mathrm{C}$. The fatty acid profile is characterized by large amounts of branched and straightchain fatty acids. The DNA G $+\mathrm{C}$ content is $41-45 \mathrm{~mol} \%$.

\section{Description of Muricauda flavescens sp. nov.}

Muricauda flavescens (fla.ves'cens. L. v. flavesco to become golden yellow; L. part. adj. flavescens becoming golden yellow).

Cells are non-motile, non-spore-forming rods that are $0 \cdot 2-0 \cdot 5 \mu \mathrm{m}$ wide by $2 \cdot 5-6 \cdot 0 \mu \mathrm{m}$ long. Gram-negative. Appendages are found on most cells (see Supplementary Figure in IJSEM Online). On MA, colonies are golden yellow in colour, glistening, circular, slightly convex and $0 \cdot 8-1 \cdot 2 \mathrm{~mm}$ in diameter after 3 days incubation at $30^{\circ} \mathrm{C}$. Optimal growth temperature is $30-37^{\circ} \mathrm{C}$. Growth occurs at $10{ }^{\circ} \mathrm{C}$, but not at $4{ }^{\circ} \mathrm{C}$. Maximum growth temperature is $44^{\circ} \mathrm{C}$. Optimal growth $\mathrm{pH}$ is around $7 \cdot 0$. Growth occurs weakly at $\mathrm{pH} 5 \cdot 0$, but not at $\mathrm{pH} 4 \cdot 5$. Optimal growth occurs in the presence of $2 \%(\mathrm{w} / \mathrm{v}) \mathrm{NaCl}$. Growth occurs in the presence of $9 \%(\mathrm{w} / \mathrm{v}) \mathrm{NaCl}$, but not without $\mathrm{NaCl}$ or in the presence of more than $10 \%(\mathrm{w} / \mathrm{v}) \mathrm{NaCl}$. No growth occurs under anaerobic conditions on MA. The predominant respiratory lipoquinone is $\mathrm{MK}-6$. The major fatty acids are iso- $\mathrm{C}_{17: 0} 3-\mathrm{OH}$, iso- $\mathrm{C}_{15: 1}$, iso- $\mathrm{C}_{15: 0}$ and $\mathrm{C}_{15: 0}$. The DNA G $+\mathrm{C}$ content (determined by HPLC) is $45 \cdot 2-$ $45.4 \mathrm{~mol} \%$. Other phenotypic properties are given in Table 1 . 
The type strain, SW $-62^{\mathrm{T}}\left(=\mathrm{KCCM} 41645^{\mathrm{T}}=\mathrm{JCM} 11812^{\mathrm{T}}\right)$, was isolated from a salt lake near Hwajinpo Beach of the East Sea in Korea. The reference strain is SW-74.

\section{Description of Muricauda aquimarina sp. nov.}

Muricauda aquimarina (a.qui.ma.ri'na. L. n. aqua water; L. adj. marinus of the sea; N.L. adj aquimarina pertaining to sea water).

Cells are non-motile, non-spore-forming rods that are $0 \cdot 2-0 \cdot 5 \mu \mathrm{m}$ wide by $2 \cdot 5-6 \cdot 0 \mu \mathrm{m}$ long. Gram-negative. Appendages are found on most cells (see Supplementary Figure in IJSEM Online). On MA, colonies are golden yellow in colour, glistening, circular, slightly convex and $0 \cdot 8-1 \cdot 2 \mathrm{~mm}$ in diameter after 3 days incubation at $30^{\circ} \mathrm{C}$. Optimal growth temperature is $30-37^{\circ} \mathrm{C}$. Growth occurs at $10^{\circ} \mathrm{C}$, but not at $4{ }^{\circ} \mathrm{C}$. Maximum growth temperature is $44^{\circ} \mathrm{C}$. Optimal growth $\mathrm{pH}$ is around $7 \cdot 0$. Growth occurs weakly at $\mathrm{pH} 5 \cdot 0$, but not at $\mathrm{pH} 4 \cdot 5$. Optimal growth occurs in the presence of $2 \%(\mathrm{w} / \mathrm{v}) \mathrm{NaCl}$. Growth occurs in the presence of $9 \%(\mathrm{w} / \mathrm{v}) \mathrm{NaCl}$, but not without $\mathrm{NaCl}$ or in the presence of more than $10 \%(\mathrm{w} / \mathrm{v}) \mathrm{NaCl}$. No growth occurs under anaerobic conditions on MA. The predominant respiratory lipoquinone is MK-6. The major fatty acids are iso- $\mathrm{C}_{15: 0}$, iso- $\mathrm{C}_{15: 1}$ and iso- $\mathrm{C}_{17: 0} 3-\mathrm{OH}$. The DNA G+C content (determined by HPLC) is $44 \cdot 1-44 \cdot 2 \mathrm{~mol} \%$. Other phenotypic properties are given in Table 1.

The type strain, SW $-63^{\mathrm{T}}\left(=\mathrm{KCCM} 41646^{\mathrm{T}}=\mathrm{JCM} 11811^{\mathrm{T}}\right)$, was isolated from a salt lake near Hwajinpo Beach of the East Sea in Korea. The reference strain is SW-72.

\section{Acknowledgements}

This work was supported by the 21C Frontier Program of Microbial Genomics and Applications (grant MG02-0401-001-1-0-0) and the National Research Laboratory research program (grants M1010400029401J000012800 and M10104000294-01J000012811) from the Ministry of Science and Technology (MOST) of the Republic of Korea.

\section{References}

Barbeyron, T., L'Haridon, S., Corre, E., Kloareg, B. \& Potin, P. (2001). Zobellia galactanovorans gen. nov., sp. nov., a marine species of Flavobacteriaceae isolated from a red alga, and classification of [Cytophaga] uliginosa (ZoBell and Upham 1944) Reichenbach 1989 as Zobellia uliginosa gen. nov., comb. nov. Int J Syst Evol Microbiol 51, 985-997.

Baumann, L. \& Baumann, P. (1981). The marine Gram-negative eubacteria; genera Photobacterium, Beneckea, Alteromonas, Pseudomonas, and Alcaligenes. In The Prokaryotes. A Handbook on Habitats, Isolation, and Identification of Bacteria, pp. 1302-1330. Edited by M. P. Starr, H. Stolp, H. G. Trüper, A. Balows \& H. G. Schlegel. Berlin: Springer.

Bowman, J. P., McCammon, S. A., Brown, J. L., Nichols, P. D. \& McMeekin, T. A. (1997). Psychroserpens burtonensis gen. nov., sp. nov., and Gelidibacter algens gen. nov., sp. nov., psychrophilic bacteria isolated from Antarctic lacustrine and sea ice habitats. Int J Syst Bacteriol 47, 670-677.

Bruns, A., Rohde, M. \& Berthe-Corti, L. (2001). Muricauda ruestringensis gen. nov., sp. nov., a facultatively anaerobic, appendaged bacterium from German North Sea intertidal sediment. Int J Syst Evol Microbiol 51, 1997-2006.

Cowan, S. T. \& Steel, K. J. (1965). Manual for the Identification of Medical Bacteria. London: Cambridge University Press.

Ezaki, T., Hashimoto, Y. \& Yabuuchi, E. (1989). Fluorometric deoxyribonucleic acid-deoxyribonucleic acid hybridization in microdilution wells as an alternative to membrane filter hybridization in which radioisotopes are used to determine genetic relatedness among bacterial strains. Int J Syst Bacteriol 39, 224-229.

Glöckner, F. O., Fuchs, B. M. \& Amann, R. (1999). Bacterioplankton compositions of lakes and oceans: a first comparison based on fluorescence in situ hybridization. Appl Environ Microbiol 65, 3721-3726.

Kirchman, D. L. (2002). The ecology of Cytophaga-Flavobacteria in aquatic environments. FEMS Microbiol Ecol 39, 91-100.

Komagata, K. \& Suzuki, K. (1987). Lipids and cell-wall analysis in bacterial systematics. Methods Microbiol 19, 161-203.

Lanyi, B. (1987). Classical and rapid identification methods for medically important bacteria. Methods Microbiol 19, 1-67.

Leifson, E. (1963). Determination of carbohydrate metabolism of marine bacteria. J Bacteriol 85, 1183-1184.

Llobet-Brossa, E., Rosselló-Mora, R. \& Amann, R. (1998). Microbial community composition of Wadden Sea sediments as revealed by fluorescence in situ hybridization. Appl Environ Microbiol 64, 2691-2696.

Pinhassi, J., Zweifel, U. L. \& Hagström, Å. (1997). Dominant marine bacterioplankton species found among colony-forming bacteria. Appl Environ Microbiol 63, 3359-3366.

Sasser, M. (1990). Identification of Bacteria by Gas Chromatography of Cellular Fatty Acids. Newark, DE: MIDI.

Stackebrandt, E. \& Goebel, B. M. (1994). Taxonomic note: a place for DNA-DNA reassociation and 16S rRNA sequence analysis in the present species definition in bacteriology. Int J Syst Bacteriol 44, 846-849.

Tamaoka, J. \& Komagata, K. (1984). Determination of DNA base composition by reverse-phase high-performance liquid chromatography. FEMS Microbiol Lett 25, 125-128.

Wayne, L. G., Brenner, D. J., Colwell, R. R. \& 9 other authors (1987). International Committee on Systematic Bacteriology. Report of the ad hoc committee on reconciliation of approaches to bacterial systematics. Int J Syst Bacteriol 37, 463-464.

Yoon, J.-H., Kim, H., Kim, S.-B., Kim, H.-J., Kim, W. Y., Lee, S. T., Goodfellow, M. \& Park, Y.-H. (1996). Identification of Saccharomonospora strains by the use of genomic DNA fragments and rRNA gene probes. Int J Syst Bacteriol 46, 502-505.

Yoon, J.-H., Lee, S. T. \& Park, Y.-H. (1998). Inter- and intraspecific phylogenetic analysis of the genus Nocardioides and related taxa based on 16S rRNA gene sequences. Int J Syst Bacteriol 48, 187-194.

Yoon, J.-H., Kim, H., Kim, I.-G., Kang, K. H. \& Park, Y.-H. (2003). Erythrobacter flavus sp. nov., a slight halophile from the East Sea in Korea. Int J Syst Evol Microbiol 53, 1169-1174.

Yurkov, V., Stackebrandt, E., Holmes, A. \& 7 other authors (1994). Phylogenetic positions of novel aerobic, bacteriochlorophyll $a$ containing bacteria and description of Roseococcus thiosulfatophilus gen. nov., sp. nov., Erythromicrobium ramosum gen. nov., sp. nov., and Erythrobacter litoralis sp. nov. Int J Syst Bacteriol 44, 427-434. 